\title{
PERFORMANCE OF SILVER MONTAZAH HENS FED MASH OR PELLETED DIETS CONTAINING CORN-WITH-COBS MEAL WITH OR WITHOUT ENZYME SUPPLEMENTATION El-Serwy, Amina A. ${ }^{1}$; M.H. Rabie ${ }^{1}$; S.A. Dorgham ${ }^{2}$ and M.E. Ghozlan² 1- Poultry Prod. Dept., Fac. Agric., Mansoura Univ., Egypt 2- Anim. Prod. Res. Inst., Agric. Res. Center, Egypt.
}

\begin{abstract}
A factorial experiment $(4 \times 2 \times 2)$ was conducted to evaluate the response of laying hens to feeding experimental diets containing graded levels of corn-with-cobs meal $\left(0,10,20\right.$ and $30 \%$ ) with or without Kemzyme ${ }^{\circledR}$ supplementation (0 and $1 \mathrm{~g} / \mathrm{kg}$ diet) in the form of mash or pellets. Thus, 16 isocaloric and isonitrogenous diets were formulated and used from 28 to 52 weeks of age. A total of 384 Silver Montazah laying hens were randomly chosen, individually caged in an open sided house and exposed to a daily photoperiod of $16 \mathrm{hr}$, and managed similarly. All hens were fed their respective experimental diets and had free access to water throughout the experimental period. The most important results obtained could be summarized as follows:

Dietary level of corn-with-cobs meal (CCM) had no significant effects on body weight change, feed consumption, egg weight, egg shape index and yolk index or serum total protein, albumin, calcium, inorganic phosphorus, or activity of alanine aminotransferase (ALT) and aspartate aminotransferase (AST) in blood serum of hens. Increasing dietary level of CCM positively affected feed conversion, egg production rate and egg mass. In addition, Haugh units and serum and egg cholesterol were significantly increased when the level of CCM reached $30 \%$. However, neither dietary enzyme supplementation nor diet form (mash vs. pellets) had significant effects on body weight change, feed consumption, feed conversion, egg production rate, egg weight, egg mass, shell thickness, egg shape index, yolk index, Haugh units or egg cholesterol, or serum levels of total protein, albumin, cholesterol, calcium, inorganic phosphorus, and activity of ALT and AST in blood serum. According to the obtained results, corn-with-cobs meal can be included up to $30 \%$ in diets of Silver Montazah laying hens, without compromising their productive performance or egg quality, with no need for pelleting the diets or adding exogenous enzymes.
\end{abstract}

Keywords: Corn-with-cobs meal, enzyme addition, diet form, laying performance.

\section{INTRODUCTION}

Compared with other cereal grains, corn (Zea mays L.) is the preferable primary energy source in poultry diets. The continuous increase in human population worldwide, particularly in developing countries, is often associated with increasing the relative prices of certain competitive animal and human feed- and foodstuffs, including corn, wheat, barley, rice and others. This necessitates an urgent need to look for cheaper or untraditional alternative feedstuffs. The whole corn-with-cobs meal, the ground product of the entire maize ear including the cobs, is an example of such feedstuffs which is efficiently used by ruminants, and there is almost no difference in the performance of feedlot animals receiving corn-with-cobs meal and animals feeding on shelled maize (FAO, 2004). For horses, corn-with-cobs meal 
(which is also termed as corn-and-cob meal, corn ear or maize ear) is usually preferred to shelled maize as it is less likely to form a doughy mass in the stomach (FAO, 2004). It has been reviewed that the high fiber content of corn-with-cobs meal restricts its use as a feed ingredient in poultry diets; however, pigs can tolerate the incorporation of such feed ingredient up to 25$50 \%$ in their diets, depending on age (FAO, 2004). In harmony with the general nutritional aspect that the nutritive value of any feed ingredient is essentially affected by its chemical composition, Martínez et al. (2008) reported that chemical compositions of maize ear and corn are similar, but maize ear has higher fibre content than corn. They also found that inclusion of maize ear in the diet for fattening rabbits increases the digestible energy content, reduces the voluntary feed intake and improves feed conversion ratio.

According to the available sources of literature, very limited information is presented on the nutritive value of corn-with-cobs meal for poultry. In this regard, Scott et al. (1976) tabulated that corn-and-cob meal contains [on dry matter (DM) basis] $7.5 \%$ crude protein, 3.0\% fat, $8.6 \%$ crude fiber, $0.04 \%$ calcium, $0.20 \%$ total $\mathrm{P}, 0.07 \%$ available $\mathrm{P}, 0.18 \%$ histidine, $0.18 \%$ lysine, $0.16 \%$ methionine, $0.16 \%$ cystine, $0.45 \%$ arginine, $0.45 \%$ phenylalanine, $0.45 \%$ glycine, $0.36 \%$ valine, $0.36 \%$ isoleucine, $0.36 \%$ threonine, $1.0 \%$ leucine and $0.09 \%$ tryptophan, and it has a metabolizable energy of 2840 $\mathrm{kcal} / \mathrm{kg}$ DM. Recently, Martínez et al. (2008) reported that chemical composition of maize ear (DM basis) was as follows: $91.9 \% \mathrm{DM}, 1.25 \%$ ash, $7.8 \%$ crude protein, $3.23 \%$ ether extract, $5.55 \%$ crude fiber, $18.0 \%$ neutral detergent fiber and $6.02 \%$ acid detergent fiber. The corresponding composition of corn cobs was as follows: 94.2, 1.94, 2.23, 0.471, 38.0, 86.1, 45.3 and $5.22 \%$ for DM, ash, crude protein, ether extract, crude fiber, neutral detergent fiber, acid detergent fiber and acid detergent lignin, respectively (Martínez et al., 2008).

On the other hand, Longe and Ogedegbe (1989) fed growing pullets (from 9 to 21 weeks old) experimental diets containing graded amounts of maize cobs (5 to $20 \%$ of the diet) and found that ME intake was significantly reduced when the dietary level of maize cob exceeded $10 \%$. They also found that protein intake was unaffected by dietary treatments but apparent nitrogen retention was significantly lower in pullets given the diet having $20 \%$ maize cob as compared to their control counterparts. Adeyemi and Familade (2003) fed laying hens on diets containing corn-cobs at levels of 5, 10, 15 and $20 \%$ of the total diet at the expense of maize. They found that hen-day production and feed per dozen eggs decreased with increasing dietary level of corn-cobs whereas egg weight and shell thickness were not significantly influenced by dietary treatments. In general, we must bear in mind that the nutritive value of a feedstuff for poultry can vary considerably depending upon its chemical composition and level of inclusion, composition and physical nature (i.e. particle size and texture) of the basal diet, type and age of the experimental birds and/or other factors.

Nowadays, most nutritionists formulate diets destined to poultry based completely on oil-seed meals, cereal grains and their by-products. Such plant feed ingredients naturally contain a variety of components (i.e. 
antinutritional substances) that cannot be digested by monogastric animals because of the lack of or insufficiency of endogenous enzyme secretions. In addition to being unavailable to the animal, these components also lower the utilization of other dietary nutrients, leading to depressed performance. Recently, the inclusion of commercial enzymes into poultry diets has become a common practice, with different degrees of success depending upon the stress, health and nutritional status of the bird. The main targets for using feed enzymes are to increase digestibility (or availability) of nutrients, to break down the antinutritional factors, to achieve the least cost feed formulations and for environmental reasons (Bedford, 1996; Bedford and Morgan, 1996; Bedford and Partridge, 2003).

Therefore, the present study was carried out to evaluate the response of laying hens to feeding mash and pelleted diets containing graded levels of corn-with-cobs meal with or without enzyme supplementation.

\section{MATERIALS AND METHODS}

A $4 \times 2 \times 2$ factorial experiment was carried out at Gimmizah Poultry Research Station, belonging to the Animal Production Research Institute, Ministry of Agriculture, Egypt. A total of 384 28-week-old Silver Montazah laying hens were randomly chosen and distributed into 16 equal experimental groups of 24 birds each (with 3 equal replications per treatment). Four isoenergetic (metabolizable energy of about $2700 \mathrm{kcal} / \mathrm{kg}$ ) and isonitrogenous (crude protein of about 15\%) experimental diets containing 4 levels of cornwith-cobs meal (CCM; 0, 10, 20 and 30\%) were formulated as mash or pellets with or without Kemzyme ${ }^{\circledR}$ supplementation ( 0 and $1 \mathrm{~g} / \mathrm{kg}$ diet). Thus, 16 experimental diets were prepared and used from 28 to 52 weeks of age. The experimental diets were formulated to meet the nutrient requirements of the local strains of laying hens, as indicated by several reports on the developed native chickens. Composition and proximate analysis of the experimental diets, used in this study, are presented in Table 1. Kemzyme ${ }^{\circledR}$ preparation contained alpha-amylase, $\beta$-glucanase, lipase, and cellulose. The hens were kept in individual cages in an open-sided laying house. All birds were exposed to a daily photoperiod of $16 \mathrm{hr}$ and kept under the same hygienic and managerial conditions.

Daily records on hen-day egg production rate (EPR) and mortality of hens were maintained throughout the whole experimental period. Feed intake $(\mathrm{FI})$, feed conversion (FC), EPR, egg weight (EW) and egg mass (EM) were determined, on a 28-d period basis, for the entire experimental period. Body weight change (BWC) and economic efficiency of production (EEP) were also estimated for the whole experimental period. EEP was calculated as 100 times net revenue divided by total costs. Net revenue (NR) was calculated as total revenues minus total costs. It also important to point out that total costs include purchasing price of pullet and total feed cost/pullet. Total revenues include sale price of spent hens and eggs. At 34 weeks of age, 6 blood samples were collected from the wing veins in non-heparinized test tubes. Blood sera were analyzed for the determination of concentrations of total 
protein (TP; Henry et al., 1964), albumin (AL; Doumas et al., 1971), cholesterol (CH; Allain et al., 1974), calcium (Ca; Tietz, 1987) and inorganic phosphorus (IP; Goldenberg and Fernandez, 1966) as well as activity of serum alanine aminotransferase (ALT) and aspartate aminotransferase (AST; Reitman and Frankel, 1957) of laying hens. At the end of the experimental period (52 weeks of age), 15 eggs per treatment were collected and used for egg quality measurements. Egg quality was measured in terms of egg weight and its components (weights of egg shell, egg yolk and egg albumen), egg shape index (ESI), shell thickness (ST), yolk index (YI) and Haugh units (HU; Haugh, 1937). Egg yolk cholesterol (EYC) contents were also determined according to the method described by Ingr et al. (1987).

Table (1): Ingredients and nutrient composition of the experimental diets $^{\S}$

\begin{tabular}{|c|c|c|c|c|}
\hline \multirow{2}{*}{ Ingredients \% } & \multicolumn{4}{|c|}{ Levels of corn-with-cobs meal (\%) } \\
\hline & 0.00 & 10.0 & 20.0 & 30.0 \\
\hline Yellow corn & 64.00 & 55.75 & 47.55 & 39.00 \\
\hline Soybean meal (44\% CP) & 17.25 & 17.25 & 17.25 & 17.20 \\
\hline Corn-with-cobs meal* & 0.00 & 10.00 & 20.00 & 30.00 \\
\hline Wheat bran & 6.50 & 4.25 & 2.00 & 0.00 \\
\hline Corn gluten meal (62\% CP) & 2.15 & 2.40 & 2.60 & 2.85 \\
\hline DL-Methionine & 0.10 & 0.10 & 0.10 & 0.10 \\
\hline L-Lysine-HCl & 0.10 & 0.10 & 0.10 & 0.10 \\
\hline Limestone & 7.70 & 7.70 & 7.70 & 7.70 \\
\hline Dicalcium phosphate & 1.60 & 1.60 & 1.60 & 1.60 \\
\hline Common salt & 0.30 & 0.30 & 0.30 & 0.30 \\
\hline Vit. \& Min. Premix ${ }^{\star \star}$ & 0.30 & 0.30 & 0.30 & 0.30 \\
\hline Commercial vegetable oil & 0.00 & 0.25 & 0.50 & 0.85 \\
\hline Total & 100.00 & 100.00 & 100.00 & 100.00 \\
\hline Price/kg diet; P.T. & 119 & 116 & 115 & 113 \\
\hline \multicolumn{5}{|c|}{ Calculated analysis (Air-dry basis: NRC, 1994) } \\
\hline ME; kcal/kg & 2701 & 2700 & 2699 & 2689 \\
\hline Crude protein (CP); \% & 15.00 & 15.00 & 15.00 & $15 . .00$ \\
\hline Ether extract (EE); \% & 3.36 & 3.40 & 3.44 & 3.47 \\
\hline Crude fiber (CF); \% & 3.44 & 3.81 & 4.18 & 4.56 \\
\hline $\mathrm{Ca} ; \%$ & 3.34 & 3.34 & 3.35 & 3.32 \\
\hline Non-phytate P; \% & 0.42 & 0.41 & 0.40 & 0.39 \\
\hline Lysine; \% & 0.79 & 0.76 & 0.73 & 0.69 \\
\hline Meth. \& Cystine & 0.62 & 0.62 & 0.60 & 0.58 \\
\hline \multicolumn{5}{|c|}{ Determined analysis (Dry matter basis: AOAC, 1990) } \\
\hline Dry matter (DM); \% & 91.85 & 90.90 & 91.25 & 90.79 \\
\hline Ash; \% & 6.05 & 6.03 & 6.01 & 6.00 \\
\hline CP; \% & 16.03 & 16.30 & 16.18 & 16.37 \\
\hline EE; \% & 3.75 & 3.83 & 3.83 & 3.86 \\
\hline CF; \% & 3.97 & 4.40 & 4.62 & 5.08 \\
\hline NFE \% & 62.05 & 60.34 & 60.61 & 59.48 \\
\hline
\end{tabular}

\$: Pelleting and enzyme addition add 7 and 3 piasters to the price per $\mathrm{kg}$ diet illustrated above.

*: The nutrient composition of corn and cobs meal was calculated according to Scott et al. (1976).

**: Vitamin and Mineral Premix supplies each $\mathrm{kg}$ of the experimental diets with the following concentrations of nutrients: Vit. A, 10000 IU; Vit. $D_{3}, 2000$ IU; Vit. E, 10 mg; Vit. $\mathrm{K}, 1 \mathrm{mg}$; Vit. $B_{1}, 1 \mathrm{mg}$; Vit. $B_{2}, 5 \mathrm{mg}$; Vit. $B_{6}, 1.5 \mathrm{mg}$; Vit. $B_{12}, 0.01 \mathrm{mg}$; Folic acid, $0.35 \mathrm{mg}$; Biotin, $0.05 \mathrm{mg}$; Pantothenic acid, $10 \mathrm{mg}$; Niacin, $30 \mathrm{mg}$; Choline chloride, $250 \mathrm{mg}$; Fe, $30 \mathrm{mg}$; Zn, $50 \mathrm{mg}$; Cu, $4 \mathrm{mg}$ and Se, $0.1 \mathrm{mg}$. 
A completely randomized block design in a factorial arrangement of treatments $(4 \times 2 \times 2), 4$ dietary levels of CCM $(0,10,20$ and $30 \%)$ with or without Kemzyme ${ }^{\circledR}$ addition ( 0 and $1 \mathrm{~g} / \mathrm{kg}$ diet) in two diet forms (mash and pellets), was used. The statistical processing of data was performed by using multifactor analysis of variance of the general linear model procedure of the Statistical Analysis System (SAS, 1990). When the main effects were significant $(P \leq 0.05)$, means were separated by Duncan's multiple range test (Duncan, 1955).

\section{RESULTS AND DISCUSSION}

Productive performance of Silver Montazah laying hens:

Regardless of the effects of diet form and enzyme addition, EPR, total EM and FC (Table 2), NR and EEP of Silver Montazah (Table 3) were significantly $(\mathrm{P}<0.05)$ affected by dietary level of corn-with-cobs meal $(\mathrm{CCM})$ during the whole experimental period (28-52 weeks of age), while BWC, total $\mathrm{FI}$ and EW were not affected (Table 2). Hens fed the CCM-containing diets exhibited superior means of EPR, total EM and FC, NR and EEP compared with those of their control counterparts (Tables 2 and 3 ).

The best EPR was accomplished by hens fed the 30\%-CCM-containing diets, followed by that of hens fed the $20 \%$-CCM-diets, and then that of birds fed the 10\%-CCM-diets, with no significant differences among them. The same trend of positive response was also observed in FC, total EM, NR and EEP of Silver Montazah laying hens. However, neither diet form (mash vs. pellets) nor enzyme addition had a significant effect on BWC, FI, FC, EPR, EW, EM and NR (Tables 2 and 3), but EEP was significantly increased due to enzyme addition (Table 3 ), regardless of the effects of other dietary factors. There were significant interactions $(P<0.05)$ between dietary CCM level and enzyme addition on FC, EPR and EM (Table 2), and NR and EEP (Table 3). The interactions between dietary CCM level and diet form were significant at $\mathrm{P}<0.05$ for FC, EPR, EM, NR and EEP (Tables 2 and 3). Enzyme addition by diet form interactions were only significant $(P<0.05)$ for $F C$, EM and EEP (Tables 2 and 3 ). The interactions among all dietary factors (i.e. ABC interactions) were significant for FC, EPR, EM, NR and EEP (Tables 2 and 3).

Since total feed intakes were approximately similar for all the experimental groups of Silver Montazah laying hens, the better productive performance (EPR, FC and EM) of hens fed the CCM-containing diets indicates that these hens could utilize their diets more efficiently than that did the control ones. The lack of significant differences in total FI among the different experimental groups of hens is an indication that CCM had no effect on the appetite of birds or palatability of diets. Also, it is interesting to note that inclusion of the CCM in the current the experimental diets increased their crude fiber contents only from 3.44 (in the control diet) to $4.56 \%$ (in the $30 \%$ CCM-diet), which were in the normal range for laying hens. Unfortunately, no reports were found in the literature on the use of corn-with-cobs meal in laying hen diets. 
El-Serwy, Amina A. et al.

Table (2): Laying performance of Sliver Montazah hens in response to feeding the experimental diets during whole experimental period (28-52 weeks of age).

\begin{tabular}{|c|c|c|c|c|c|c|}
\hline Treatments $\$$ & $\begin{array}{l}\text { BWC } \\
\text { (g) }\end{array}$ & $\begin{array}{c}\text { FI } \\
\text { (kg/hen) }\end{array}$ & $\begin{array}{c}\text { FC } \\
(\mathbf{k g : k g})\end{array}$ & $\begin{array}{l}\text { EPR } \\
(\%)\end{array}$ & $\begin{array}{l}\text { EW } \\
(\mathrm{g})\end{array}$ & $\begin{array}{c}\text { EMM } \\
\text { (kg/hen) }\end{array}$ \\
\hline $\begin{aligned} & \text { A: } 1(0.0 \%) \\
& 2(10 \%) \\
& 3(20 \%) \\
& 4(30 \%)\end{aligned}$ & $\begin{array}{l}504.89 \\
514.53 \\
507.65 \\
514.16\end{array}$ & $\begin{array}{l}20.279 \\
20.235 \\
20.300 \\
20.405\end{array}$ & $\begin{array}{l}5.51^{\mathrm{b}} \\
5.32^{\mathrm{a}} \\
5.30^{\mathrm{a}} \\
5.28^{\mathrm{a}}\end{array}$ & $\begin{array}{l}50.93^{\mathrm{b}} \\
52.62^{\mathrm{a}} \\
52.96^{\mathrm{a}} \\
53.41^{\mathrm{a}}\end{array}$ & $\begin{array}{l}44.94 \\
44.92 \\
44.96 \\
44.97\end{array}$ & $\begin{array}{l}3.678^{c} \\
3.803^{b} \\
3.830^{b} \\
3.863^{a}\end{array}$ \\
\hline SEM & 3.19 & 2.354 & 0.12 & 3.02 & 0.18 & 0.210 \\
\hline Sig. level & NS & NS & & & NS & \\
\hline$B: \begin{array}{l}1(0 \mathrm{~g}) \\
2(1 \mathrm{~g})\end{array}$ & $\begin{array}{l}508.35 \\
512.26\end{array}$ & $\begin{array}{l}20.311 \\
20.299\end{array}$ & $\begin{array}{l}5.38 \\
5.32\end{array}$ & $\begin{array}{l}52.21 \\
52.74\end{array}$ & $\begin{array}{l}44.95 \\
44.95\end{array}$ & $\begin{array}{l}3.773 \\
3.813\end{array}$ \\
\hline SEM & 0.89 & 3.112 & 0.10 & 4.00 & 0.18 & 0.182 \\
\hline Sig. Tevel & NS & NS & NS & NS & NS & NS \\
\hline $\begin{array}{r}\text { C: } 1 \text { Mash } \\
2 \text { Pellet }\end{array}$ & $\begin{array}{l}507.63 \\
512.99\end{array}$ & $\begin{array}{l}20.295 \\
20.317\end{array}$ & $\begin{array}{l}5.35 \\
5.33\end{array}$ & $\begin{array}{l}52.38 \\
52.58\end{array}$ & $\begin{array}{l}44.96 \\
44.94\end{array}$ & $\begin{array}{l}3.795 \\
3.812\end{array}$ \\
\hline SEIM & 1.01 & 3.001 & 0.09 & 2.51 & 0.15 & 0.153 \\
\hline Siq. level & NS & NS & NS & NS & NS & NS \\
\hline$A B: 1(1 \times 1)$ & 503.12 & 20.335 & 5.56 & 50.65 & 44.93 & 3.655 \\
\hline $2(2 \times 1)$ & 514.58 & 20.228 & 5.35 & 52.30 & 44.91 & 3.779 \\
\hline $3(3 \times 1)$ & 505.73 & 20.284 & 5.32 & 52.71 & 44.96 & 3.813 \\
\hline $4(4 \times 1)$ & 510.00 & 20.398 & 5.35 & 52.96 & 44.01 & 3.809 \\
\hline $5(1 \times 2)$ & 506.66 & 20.222 & 5.46 & 51.20 & 44.97 & 3.703 \\
\hline $6(2 \times 2)$ & 514.47 & 20.242 & 5.32 & 52.65 & 44.94 & 3.804 \\
\hline $7(3 \times 2)$ & 509.58 & 20.316 & 5.27 & 52.85 & 44.95 & 3.852 \\
\hline $8(4 \times 2)$ & 518.33 & 20.417 & 5.28 & 53.48 & 44.94 & 3.870 \\
\hline SEM & 1.02 & 2.015 & 0.15 & 2.46 & 0.18 & 0.172 \\
\hline Sig. Tevel & NS & NS & & & NS & \\
\hline AC: $1(1 \times 1)$ & 499.58 & 20.261 & 5.53 & 50.77 & 44.94 & 3.666 \\
\hline $2(2 \times 1)$ & 513.75 & 20.250 & 5.34 & 52.52 & 44.93 & 3.796 \\
\hline $3(3 \times 1)$ & 502.81 & 20.267 & 5.37 & 52.24 & 44.97 & 3.777 \\
\hline $4(4 \times 1)$ & 514.38 & 20.400 & 5.29 & 53.33 & 44.99 & 3.855 \\
\hline $5(1 \times 2)$ & 510.50 & 20.298 & 5.50 & 51.08 & 44.94 & 3.689 \\
\hline $6(2 \times 2)$ & 515.31 & 20.220 & 5.37 & 52.15 & 44.91 & 3.767 \\
\hline $7(3 \times 2)$ & 512.50 & 20.334 & 5.31 & 53.00 & 44.95 & 3.832 \\
\hline $8(4 \times 2)$ & 513.95 & 20.415 & 5.27 & 53.55 & 44.96 & 3.874 \\
\hline SEIM & 1.05 & 3.589 & 0.08 & 4.25 & 0.17 & 0.223 \\
\hline Siq. Tevel & NS & NS & & & NS & \\
\hline BC: $1(1 \times 1)$ & 504.79 & 20.313 & 5.42 & 51.91 & 44.95 & 3.750 \\
\hline $2(2 \times 1)$ & 510.46 & 20.275 & 5.31 & 52.83 & 44.96 & 3.820 \\
\hline $3(1 \times 2)$ & 511.92 & 20.310 & 5.35 & 52.53 & 44.95 & 3.796 \\
\hline $4(2 \times 2)$ & 514.06 & 20.324 & 5.34 & 52.64 & 44.93 & 3.807 \\
\hline SEM & 0.89 & 2.445 & 0.16 & 4.00 & 0.19 & 0.128 \\
\hline Siq. level & NS & NS & & NS & NS & \\
\hline BC: $1(1 \times 1 \times 1)$ & 497.70 & 20.319 & 5.59 & 50.38 & 44.92 & 3.632 \\
\hline $2(2 \times 1 \times 1)$ & 501.46 & 20.255 & 5.40 & 51.85 & 44.90 & 3.749 \\
\hline $3(3 \times 1 \times 1)$ & 512.91 & 20.279 & 5.33 & 52.54 & 44.97 & 3.801 \\
\hline $4(4 \times 1 \times 1)$ & 514.58 & 20.363 & 5.32 & 52.90 & 45.03 & 3.825 \\
\hline $5(1 \times 2 \times 1)$ & 500.00 & 20.213 & 5.47 & 51.15 & 44.93 & 3.697 \\
\hline $6(2 \times 2 \times 1)$ & 505.62 & 20.254 & 5.28 & 53.08 & 44.97 & 3.839 \\
\hline $7(3 \times 2 \times 1)$ & 508.54 & 20.261 & 5.26 & 53.27 & 44.97 & 3.849 \\
\hline $8(4 \times 2 \times 1)$ & 520.20 & 20.410 & 5.25 & 53.79 & 44.95 & 3.887 \\
\hline $9(1 \times 1 \times 2)$ & 508.54 & 20.353 & 5.53 & 50.93 & 44.95 & 3.677 \\
\hline $10(2 \times 1 \times 2)$ & 511.87 & 20.214 & 5.32 & 52.49 & 44.92 & 3.796 \\
\hline $11(3 \times 1 \times 2)$ & 516.25 & 20.263 & 5.29 & 53.00 & 44.94 & 3.830 \\
\hline $12(4 \times 1 \times 2)$ & 514.37 & 20.382 & 5.26 & 53.55 & 44.99 & 3.874 \\
\hline $13(1 \times 2 \times 2)$ & 511.45 & 20.242 & 5.46 & 5130 & 44.94 & 3.707 \\
\hline $14(2 \times 2 \times 2)$ & 513.54 & 20.102 & 5.27 & 52.73 & 44.91 & 3.811 \\
\hline $15(3 \times 2 \times 2)$ & 511.45 & 20.381 & 5.31 & 53.08 & 44.97 & 3.837 \\
\hline $16(4 \times 2 \times 2)$ & 516.45 & 20.425 & 5.27 & 53.51 & 44.92 & 3.874 \\
\hline SEM & 1.18 & 4.021 & 0.17 & 4.85 & 0.18 & 0.321 \\
\hline Sig. level & NS & NS & & & NS & \\
\hline
\end{tabular}

\$: A, B and C refer to dietary level of corn-with-cobs meal, enzyme addition and diet form, respectively.

a-c: For each of the main factors, means bearing common superscripts are not significantly different $(P \leq 0.05)$.

NS: Not significant, *: Significant at $P<0.05$. 
In this regard, however, Longe and Ogedegbe (1989) fed growing pullets (from 9 to 21 weeks old) experimental diets containing graded amounts of maize cobs (5 to $20 \%$ of the diet) and found that ME intake was significantly reduced when the dietary level of maize cob exceeded $10 \%$. They also found that protein intake was unaffected by dietary treatments but apparent nitrogen retention was significantly lower in pullets given the diet having $20 \%$ maize cob as compared to their control counterparts. In a later study, Adeyemi and Familade (2003) fed laying hens on diets containing corn-cobs at levels of $5,10,15$ and $20 \%$ of the total diet at the expense of maize. They found that hen-day production and feed per dozen eggs decreased with increasing dietary level of corn-cobs whereas egg weight and shell thickness were not significantly influenced by dietary treatments. Working with rabbits, Martínez et al. (2008) evaluated the nutritive value of maize ear (incorporated at 20 and $40 \%$ of the diet) for rabbits and found that the inclusion of maize ear in the diet increases the digestible energy content, reduces the voluntary feed intake and improves feed conversion on fattening rabbits.

According to the scientific literature, inconsistent responses of laying hens to feeding the enzyme-supplemented diets were observed. Several reports have indicated beneficial effects of enzyme addition to laying hen diets (e.g. Van der Klis et al., 1997; Jackson et al., 1999; Attia et al., 2001; Jalal and Scheideler, 2001; Yakout et al., 2003; El-Deek et al., 2003), while some others failed to observe positive effects (Al Bustany and Elwinger, 1988; Francesch et al., 1995; Senkoylu et al., 2004). The insignificant effect of dietary enzyme supplementation on the productive performance of laying hens, observed in the present study, is in accordance with the results obtained by Al Bustany and Elwinger (1988), who found no significant effects on performance of laying hens when $\beta$-glucanase was added to barley-based diets. In line also with the present findings, Francesch et al. (1995) reported that there were no significant differences in rate of lay, daily feed intake and body weight gain of laying hens in response to feeding enzymesupplemented diets. Recently, Senkoylu et al. (2004) observed no effect of enzyme addition on the productive performance of laying hens in one trial but feed conversion was improved in another trial due to enzyme supplementation.

On the other hand, Van der Klis et al. (1997) reported that production performance (except feed conversion ratio) was significantly improved by dietary supplementation of phytase. Jackson et al. (1999) concluded that $\beta$ mannanase is capable of increasing egg weight in commercial layers at early stages of production, and increasing egg production, particularly delaying the postpeak decline in productivity. Attia et al. (2001) reported that phytase and/or a multienzyme mixture (Optizyme) could overcome the negative effects of feeding rice bran-based diet on productive and reproductive performance of Norfa laying hens. Similarly, Jalal and Scheideler (2001) indicated that supplementation of phytase in normal; corn-soybean meal diets improved feed intake, feed conversion and egg mass while egg production and egg weight were not affected. In addition, Yakout et al. (2003) demonstrated that productive performance of Mandarah laying hens were 
significantly improved in response to enzyme supplementation (Bio-Nutra ${ }^{\circledR}$ ) to diets of different energy levels. Moreover, El-Deek et al. (2003) reported that addition of multi-enzyme mixture to $60 \%$ barley-containing diet improved egg production and egg mass.

These inconsistent responses of poultry species to dietary enzyme supplementation are expected and depend on the effectiveness of feed enzymes. The latter can vary considerably depending upon on a variety of factors relating to enzyme (i.e. type of enzyme preparation, its biological activity, level of addition, degree of specificity to substrate and its stability to feed processing or storage conditions), bird (i.e. age, breed or strain, nutritional, physiological and stress status) and diet (i.e. composition, form, physical features and method of processing); feeding programs and housing systems may also be involved.

In the present study, it was observed that Silver Montazah laying hens receiving their experimental diets in mash form performed approximately similar as did those given the pellets, suggesting no significant impact of diet form on the efficiency of feed utilization and thereby the productive performance. This insignificant effect of diet form (mash versus pellets) on hens' productivity, reported herein, is in line with the suggestion of McCracken (2002), who presented an excellent review on the effects of physical processing on the nutritive value of poultry diets and pointed out that laying hens can perform equally well whether their diet is supplies as mash or pellets. In addition, working with broiler chicks, McCracken et al. (1993) observed no significant differences in apparent metabolizable energy contents of a diet offered as mash or pellets after steam conditioning at $75^{\circ} \mathrm{C}$ for $1 \mathrm{~min}$.

However, Almirall et al. (1997) found that feeding pelleted diets increased egg production and egg weight, and improved the food efficiency of laying hens in summer season. Similarly, Wahlström et al. (1999) reported that hens fed crumbled diet compared with mash diet had significantly superior feed conversion ratio, and higher body weight, egg weight and egg mass production, suggesting a higher nutritive value for the crumbled diet. Moreover, Zelenka (2003) indicated that steam pelleting increased apparent digestibility of all organic nutrients in 65-day-old Ross hybrid male chickens. With growing ducklings, Rabie (2004) found that birds fed on pellets exhibited higher means of live body weight, weight gain and feed conversion, and superior CP and EE digestibility compared with those fed on the mash diets.

\section{Egg quality of Silver Montazah laying hens:}

Irrespective of the effects of diet form and enzyme addition, hens fed the $10 \%$ - and $20 \%-\mathrm{CCM}$ diets produced eggs of superior ST $(\mathrm{P}<0.05)$ as compared to those of the control birds, with no significant differences between them (Table 3). Also, hens fed the 30\%-CCM diets produced eggs with ST that was not significantly different from that of the control birds. It was interesting to observe that hens fed the 30\%-CCM diets produced eggs with the best mean of $\mathrm{HU}(\mathrm{P}<0.05)$ compared with the other experimental groups, with no significant differences among them (Table 3). 
Table (3): Egg quality and economic efficiency of 52-week-old Sliver Montazah laying hens in response to feeding the experimental diets

\begin{tabular}{|c|c|c|c|c|c|c|}
\hline Treatments $^{\S}$ & $\mathrm{ST}(\mathrm{mm} \times 100)$ & ESI & YI & $\mathrm{HU}$ & NR (L.E.) & EEP (\%) \\
\hline A: $1(0.0 \%)$ & $30.72^{b}$ & 0.745 & 0.448 & $81.63^{b}$ & $26.77^{5}$ & $89.19^{b}$ \\
\hline $2(10 \%)$ & $32.56^{a}$ & 0.750 & 0.444 & $82.97^{b}$ & $28.27^{a}$ & $94.40^{a b}$ \\
\hline $3(20 \%)$ & $32.32^{\mathrm{a}}$ & 0.752 & 0.445 & $81.82^{b}$ & $28.50^{\mathrm{a}}$ & $94.97^{a b}$ \\
\hline $4(30 \%)$ & $29.32^{b}$ & 0.748 & 0.447 & $84.26^{a}$ & $28.80^{\mathrm{a}}$ & $95.64^{a}$ \\
\hline SEIM & 1.64 & 0.002 & 0.007 & 4.19 & 1.44 & 4.85 \\
\hline Sig. level & & NS & NS & & & \\
\hline$B: 1(0 \mathrm{~g})$ & 30.99 & 0.748 & 0.447 & 82.30 & 27.87 & $90.90^{b}$ \\
\hline $2(1 \mathrm{~g})$ & 31.46 & 0.749 & 0.445 & 83.04 & 28.29 & $94.25^{a}$ \\
\hline SEM & 1.63 & 0.003 & 0.004 & 4.08 & 1.68 & 5.01 \\
\hline Sig. Tevel & NS & NS & NS & NS & NS & \\
\hline C : 1 Mash & 31.17 & 0.747 & 0.453 & 82.19 & 28.04 & 93.57 \\
\hline 2 Pellet & 31.29 & 0.750 & 0.438 & 82.43 & 28.13 & 93.58 \\
\hline SEIM & 1.60 & 0.004 & 0.003 & 4.19 & 1.75 & 5.30 \\
\hline Sig. Tevel & NS & NS & NS & NS & NS & NS \\
\hline AB: $1(1 \times 1)$ & 29.80 & 0.748 & 0.449 & 81.07 & 26.50 & 88.15 \\
\hline $2(2 \times 1)$ & 32.02 & 0.752 & 0.449 & 81.90 & 28.02 & 93.65 \\
\hline $3(3 \times 1)$ & 33.20 & 0.742 & 0.438 & 82.00 & 28.32 & 94.50 \\
\hline $4(4 \times 1)$ & 28.95 & 0.750 & 0.451 & 84.25 & 28.64 & 95.31 \\
\hline $5(1 \times 2)$ & 31.62 & 0.741 & 0.447 & 82.20 & 27.04 & 90.21 \\
\hline $6(2 \times 2)$ & 33.10 & 0.749 & 0.438 & 84.05 & 28.51 & 95.14 \\
\hline $7(3 \times 2)$ & 31.45 & 0.762 & 0.451 & 81.65 & 28.67 & 95.45 \\
\hline $8(4 \times 2)$ & 29.70 & 0.745 & 0.443 & 84.27 & 28.95 & 96.17 \\
\hline SEM & 3.16 & 0.007 & 0.004 & 2.15 & 1.80 & 4.82 \\
\hline Sig. Tevel & & NS & NS & & & \\
\hline AC: $1(1 \times 1)$ & 30.87 & 0.738 & 0.450 & 81.60 & 27.08 & 90.49 \\
\hline $2(2 \times 1)$ & 32.52 & 0.749 & 0.452 & 83.52 & 28.21 & 94.27 \\
\hline $3(3 \times 1)$ & 3252 & 0750 & 0.463 & 8242 & 28.46 & 9509 \\
\hline $4(4 \times 1)$ & 28.75 & 0.751 & 0.449 & 84.12 & $\begin{array}{l}20.40 \\
28.78\end{array}$ & 95.81 \\
\hline $5(1 \times 2)$ & 30.55 & 0.751 & 0.445 & 81.67 & 26.84 & 89.26 \\
\hline $6(2 \times 2)$ & 32.60 & 0.752 & 0.436 & 82.42 & 28.33 & 94.53 \\
\hline $7(3 \times 2)$ & 32.12 & 0.754 & 0.427 & 81.23 & 28.52 & 94.86 \\
\hline $8(4 \times 2)$ & 29.90 & 0.745 & 0.446 & 84.40 & 28.82 & 95.67 \\
\hline SEIM & 1.72 & 0.032 & 0.002 & 2.84 & $\frac{2.05}{1 . .35}$ & 4.99 \\
\hline Sig. Tevel & & NS & NS & & & \\
\hline$B C: 1(1 \times 1)$ & 30.88 & 0.748 & 0.451 & 82.62 & 27.65 & 92.24 \\
\hline $2(2 \times 1)$ & 31.45 & 0.746 & 0.455 & 83.21 & 28.43 & 94.89 \\
\hline $3(1 \times 2)$ & 31.10 & 0.748 & 0.442 & 81.98 & 28.10 & 93.56 \\
\hline $4(2 \times 2)$ & 31.48 & 0.752 & 0.434 & 82.87 & 28.15 & 93.60 \\
\hline SEM & 3.12 & 0.021 & 0.011 & 3.41 & $\frac{20.10}{1.91}$ & 4.21 \\
\hline Sig. level & NS & NS & NS & & NS & \\
\hline$B C: 1(1 \times 1 \times 1)$ & 30.05 & 0.741 & 0.447 & 80.60 & 26.32 & 87.72 \\
\hline $2(2 \times 1 \times 1)$ & 3090 & 0751 & 0.464 & 8290 & 27.73 & 9271 \\
\hline $3(3 \times 1 \times 1)$ & 32.85 & 0.746 & 0.444 & 84.25 & 28.10 & 93.83 \\
\hline $4(4 \times 1 \times 1)$ & 29.75 & 0.753 & 0.451 & 82.75 & 28.43 & 94.72 \\
\hline $5(1 \times 2 \times 1)$ & 31.70 & 0.735 & 0.454 & 82.60 & 27.08 & 90.49 \\
\hline $6(2 \times 2 \times 1)$ & 34.15 & 0.748 & 0.439 & 84.15 & 28.69 & 95.82 \\
\hline $7(3 \times 2 \times 1)$ & 32.20 & 0.754 & 0.481 & 80.60 & 28.83 & 96.35 \\
\hline $8(4 \times 2 \times 1)$ & 27.75 & 0.748 & 0.446 & 85.50 & 29.13 & 96.89 \\
\hline $9(1 \times 1 \times 2)$ & 29.55 & 0.756 & 0.451 & 81.55 & 26.68 & 88.59 \\
\hline $10(2 \times 1 \times 2)$ & 33.15 & 0.753 & 0.435 & 80.90 & 28.32 & 94.59 \\
\hline $11(3 \times 1 \times 2)$ & 33.55 & 0.739 & 0.433 & 79.75 & 28.55 & 95.17 \\
\hline $12(4 \times 1 \times 2)$ & 28.15 & 0.746 & 0.452 & 85.75 & 28.86 & 95.90 \\
\hline $13(1 \times 2 \times 2)$ & 31.55 & 0.747 & 0.440 & 81.80 & 27.01 & 89.93 \\
\hline $14(2 \times 2 \times 2)$ & 32.05 & 0.751 & 0.437 & 83.95 & 28.34 & 94.46 \\
\hline $15(3 \times 2 \times 2)$ & 30.70 & 0.769 & 0.421 & 82.71 & 28.50 & 94.56 \\
\hline $16(4 \times 2 \times 2)$ & 31.65 & 0.743 & 0.439 & 83.05 & 28.77 & 95.44 \\
\hline SEM & 2.85 & 0.015 & 0.004 & 4.02 & 1.82 & 3.89 \\
\hline Sig. Teve & & & & & & \\
\hline
\end{tabular}

§: A, B and C refer to dietary level of corn-with-cobs meal, enzyme addition and diet form respectively.

a-c: For each of the main factors, means bearing common superscripts are not significantly different ( $P \leq 0.05)$.

NS: Not significant, *: Significant at $P<0.05$. 
Dietary level of CCM had no significant effect on ESI and YI of eggs produced by 52-week-old Silver Montazah laying hens, regardless of the effects of other dietary factors (Table 3 ). However, neither dietary enzyme supplementation nor diet form (mash vs. pellets) had a significant effect on egg quality traits, measured in the present study, regardless of the effects of other dietary factors (Table 3).

There were significant interactions $(P<0.05)$ between dietary $\mathrm{CCM}$ level and enzyme addition on ST and HU whereas ESI and YI were not affected (Table 3). The interactions between dietary CCM level and diet form were also significant $(\mathrm{P}<0.05)$ for $\mathrm{ST}$ and $\mathrm{HU}$ but $\mathrm{ESI}$ and $\mathrm{YI}$ were not affected. Enzyme addition by diet form interactions were only significant $(\mathrm{P}<0.05)$ for HU while ST, ESI and $\mathrm{YI}$ were not affected. The interactions among all dietary factors (i.e. $\mathrm{ABC}$ interactions) were significant $(\mathrm{P}<0.05)$ for ST, ESI, YI and HU (Table 3).

The lack of positive effects of dietary enzyme supplementation on egg quality traits of Silver Montazah laying hens is in accordance with the findings of Wu et al. (2005), who found that feeding enzyme-supplemented diets exerted no significant effect on most of egg quality parameters. In the meantime, Yakout et al. (2003) reported that enzyme supplementation had no effect on egg components but significantly improved egg weight. However, Roberts et al. (2006) reported a positive effect for using the commercial enzyme products in laying hen diets on shell thickness.

The insignificant effects of the physical form of the diet (mash versus pellets) on egg quality traits in the present study are in harmony with those reported by Deaton et al. (1989) who compared the performance of laying hens fed corn ground using a hammer mill or a roller mill, resulting in different particle size of grain, and obtained comparable performance (in terms of EPR, EW, FI and FC) and egg quality (egg break force) over three consecutive trials. In accord with the present results, Berto et al. (2007) evaluated the performance and egg quality of Japanese quails fed diets containing different corn and limestone particle sizes. They found that dietary treatments had no significant effects on quail performance or egg quality.

Blood parameters of Silver Montazah laying hens:

It is interesting to point out that the determination of blood measurements was performed when the hens were at 34 weeks of age (during the peak production period) in order to mirror some indications on the metabolic and/or physiological status of the bird. Apart from the effects of diet form and enzyme addition, all blood serum parameters, measured herein, [total protein (TP), albumen (AL), total calcium (Ca) and inorganic phosphorus (IP) as well as serum activity of alanine aspartate aminotransferase (AST)] were not significantly affected by dietary CCM level, except for the level of serum cholesterol $(\mathrm{CH})$ which was significantly $(\mathrm{P}<0.05)$ higher in hens fed the $30 \%-\mathrm{CCM}$ diets compared with the control birds (Table 4). Hens fed the $20 \%-C C M$ diets also exhibited an insignificant increase in serum $\mathrm{CH}$ as compared to the other experimental groups. Similarly, hens fed the 30\%-CCM diets exhibited significantly $(P<0.05)$ higher level of egg yolk cholesterol (EYC) compared with their control counterparts. 
Table (4): Blood serum parameters and egg yolk cholesterol of 34-week-old Sliver Montazah laying hens in response to feeding the experimental diets

\begin{tabular}{|c|c|c|c|c|c|c|c|c|}
\hline Treatments & $\begin{array}{c}\mathrm{TP} \\
(\mathrm{g} / \mathrm{dL})\end{array}$ & $\begin{array}{c}A L \\
(g / d L)\end{array}$ & $\begin{array}{c}\mathrm{Ca} \\
(\mathrm{mg} / \mathrm{dl})\end{array}$ & $\begin{array}{c}\mathrm{IP} \\
(\mathrm{mg} / \mathrm{dL})\end{array}$ & $\begin{array}{c}\mathrm{CH} \\
(\mathrm{mg} / \mathrm{dL})\end{array}$ & $\begin{array}{c}\text { EYC } \\
\text { mg/g yolk }\end{array}$ & $\begin{array}{l}\text { AST } \\
\text { (U/L) }\end{array}$ & $\begin{array}{c}\text { ALT } \\
\text { (U/L) }\end{array}$ \\
\hline A: $1(0.0 \%)$ & 4.79 & $\frac{187}{1.27}$ & 17.15 & 7.13 & $111.08^{b}$ & $13.51^{\mathrm{b}}$ & 130.58 & 21.58 \\
\hline $2(10 \%)$ & 4.68 & 1.42 & 17.00 & 7.10 & $112.47^{\mathrm{b}}$ & $13.65^{b}$ & 133.27 & 22.00 \\
\hline $3(20 \%)$ & 4.71 & 1.37 & 16.95 & 7.01 & $116.49^{a}$ & $14.28^{\mathrm{ab}}$ & 134.08 & 20.50 \\
\hline $4(30 \%)$ & 4.89 & 1.34 & 16.81 & 6.94 & $119.57^{a}$ & $15.41^{a}$ & 133.55 & 20.66 \\
\hline SEM & 0.26 & 0.11 & 0.65 & 0.53 & 6.45 & 0.66 & 1.65 & 0.53 \\
\hline Sig. level & NS & NS & NS & NS & & & NS & NS \\
\hline$B: 1(0 \mathrm{~g})$ & 4.81 & 1.35 & 17.85 & 7.08 & 117.16 & 14.02 & 132.86 & 21.69 \\
\hline $2(1 \mathrm{~g})$ & 4.94 & 1.43 & 17.90 & 7.02 & 116.45 & 13.41 & 132.30 & 20.86 \\
\hline SEM & 0.19 & 0.09 & 1.58 & 0.60 & 4.50 & 0.49 & 1.12 & 0.40 \\
\hline Sig. level & NS & NS & NS & NS & NS & NS & NS & NS \\
\hline C : 1 Mash & 4.87 & 1.38 & 17.88 & 7.11 & 113.51 & 13.71 & 132.79 & 21.45 \\
\hline 2 Pellet & 4.97 & 1.34 & 17.75 & 7.05 & 113.30 & 13.20 & 132.50 & 20.87 \\
\hline SEM & 0.19 & 0.08 & 1.71 & 0.15 & 4.53 & 0.49 & 1.10 & 0.38 \\
\hline Sig. Tevel & NS & NS & NS & NS & NS & NS & NS & NS \\
\hline$A B: 1(1 \times 1)$ & 4.79 & 1.34 & 17.78 & 7.18 & 118.05 & 14.30 & 132.00 & 21.50 \\
\hline $2(2 \times 1)$ & 4.74 & 1.39 & 17.71 & 7.14 & 117.61 & 14.02 & 134.00 & 22.66 \\
\hline $3(3 \times 1)$ & 4.76 & 1.43 & 17.69 & 7.19 & 112.38 & 13.25 & 133.83 & 20.16 \\
\hline $4(4 \times 1)$ & 4.81 & 1.37 & 17.72 & 7.16 & 119.27 & 14.22 & 131.33 & 21.66 \\
\hline $5(1 \times 2)$ & 4.85 & 1.43 & 17.73 & 7.13 & 113.10 & 13.50 & 129.16 & 21.66 \\
\hline $6(2 \times 2)$ & 4.81 & 1.41 & 17.75 & 7.17 & 107.33 & 13.00 & 131.83 & 20.66 \\
\hline $7(3 \times 2)$ & 4.89 & 1.42 & 17.70 & 7.19 & 109.77 & 14.30 & 134.33 & 20.83 \\
\hline $8(4 \times 2)$ & 4.94 & 1.39 & 17.72 & 7.18 & 115.71 & 13.08 & 134.66 & 20.16 \\
\hline SEM & 0.37 & 0.17 & 2.27 & 0.35 & 8.65 & 0.93 & 2.34 & 0.76 \\
\hline Siq. Tevel & NS & NS & NS & NS & & NS & NS & \\
\hline$A C: 1(1 \times 1)$ & 4.69 & 1.42 & 17.69 & 7.09 & 116.32 & 14.22 & 131.33 & 22.50 \\
\hline $2(2 \times 1)$ & 4.64 & 1.59 & 17.74 & 7.11 & 113.16 & 13.25 & 132.16 & 22.00 \\
\hline $3(3 \times 1)$ & 4.76 & 1.41 & 17.72 & 7.17 & 111.88 & 14.30 & 134.33 & 20.00 \\
\hline $4(4 \times 1)$ & 4.78 & 1.40 & 17.68 & 7.12 & 112.66 & 13.30 & 133.33 & 21.33 \\
\hline $5(1 \times 2)$ & 4.75 & 1.32 & 17.70 & 7.14 & 109.82 & 13.58 & 129.83 & 20.66 \\
\hline $6(2 \times 2)$ & 4.79 & 1.30 & 17.71 & 7.08 & 113.77 & 13.77 & 133.66 & 21.33 \\
\hline $7(3 \times 2)$ & 4.87 & 1.44 & 17.73 & 7.18 & 113.27 & 13.25 & 133.83 & 21.00 \\
\hline $8(4 \times 2)$ & 4.88 & 1.32 & 17.69 & 7.17 & 116.32 & 14.22 & 132.66 & 20.20 \\
\hline SEIM & 0.36 & 0.17 & 0.56 & 0.35 & 9.08 & 1.20 & 3.31 & 0.67 \\
\hline Sig. level & NS & NS & NS & NS & & NS & & \\
\hline BC: 1 (1x1) & 4.70 & 1.36 & 17.71 & 7.11 & 116.33 & 13.81 & 133.33 & 22.41 \\
\hline $2(2 \times 1)$ & 481 & 139 & 1770 & 708 & 11669 & 1361 & 13225 & 2050 \\
\hline $3(1 \times 2)$ & 4.84 & 1.36 & 17.65 & 7.14 & 117.33 & 14.08 & 13225 & 2057 \\
\hline $4(2 \times 2)$ & 4.82 & 1.43 & 17.68 & 7.11 & 114.27 & 13.33 & 132.75 & 21.16 \\
\hline SEM & 0.27 & 0.13 & 1.42 & 0.52 & 6.25 & 0.69 & 1.73 & 0.54 \\
\hline Sig. level & NS & NS & NS & NS & NS & NS & NS & \\
\hline BC: $1(1 \times 1 \times 1)$ & 4.66 & 1.39 & 17.64 & 7.13 & 124.66 & 15.44 & 133.66 & 23.00 \\
\hline $2(2 \times 1 \times 1)$ & 4.70 & 1.42 & 17.65 & 7.07 & 115.00 & 13.66 & 132.00 & 23.33 \\
\hline $3(3 \times 1 \times 1)$ & 4.81 & 1.49 & 17.68 & 7.09 & 111.77 & 13.16 & 137.33 & 20.33 \\
\hline $4(4 \times 1 \times 1)$ & 4.84 & 1.41 & 17.67 & 7.13 & 113.88 & 13.00 & 130.33 & 23.00 \\
\hline $5(1 \times 2 \times 1)$ & 4.82 & 1.41 & 17.65 & 7.17 & 117.99 & 13.01 & 129.00 & 22.00 \\
\hline $6(2 \times 2 \times 1)$ & 4.63 & 1.45 & 17.68 & 7.07 & 111.33 & 12.83 & 132.33 & 20.66 \\
\hline $7(3 \times 2 \times 1)$ & 4.76 & 1.34 & 17.70 & 7.09 & 112.00 & 15.44 & 131.33 & 19.66 \\
\hline $8(4 \times 2 \times 1)$ & 4.83 & 1.49 & 17.65 & 7.11 & 111.44 & 13.16 & 136.33 & 19.66 \\
\hline $9(1 \times 1 \times 2)$ & 4.80 & 1.32 & 17.68 & 7.16 & 109.38 & 12.12 & 130.33 & 20.00 \\
\hline $10(2 \times 1 \times 2)$ & 4.79 & 1.43 & 17.69 & 7.13 & 120.22 & 14.38 & 136.00 & 22.00 \\
\hline $11(3 \times 1 \times 2)$ & 4.72 & 1.38 & 17.62 & 7.12 & 113.00 & 13.33 & 130.33 & 20.00 \\
\hline $12(4 \times 1 \times 2)$ & 4.56 & 1.48 & 17.64 & 7.11 & 124.66 & 15.44 & 132.33 & 20.33 \\
\hline $13(1 \times 2 \times 2)$ & 4.71 & 1.45 & 17.70 & 7.09 & 118.21 & 14.00 & 129.33 & 21.33 \\
\hline $14(2 \times 2 \times 2)$ & 4.78 & 1.41 & 17.59 & 7.15 & 113.33 & 13.16 & 131.33 & 20.66 \\
\hline $15(3 \times 2 \times 2)$ & 4.80 & 1.39 & 17.62 & 7.13 & 117.55 & 13.17 & 137.33 & 22.00 \\
\hline $16(4 \times 2 \times 2)$ & 4.79 & 1.42 & 17.71 & 7.12 & 117.99 & 13.01 & 133.00 & 20.66 \\
\hline SEM & 0.52 & 0.21 & 2.80 & 0.14 & 12.01 & 1.12 & 3.18 & 1.25 \\
\hline Sia level & NS & NS & NS & NS & & & & \\
\hline
\end{tabular}

\$: A, B and C refer to dietary level of corn-with-cobs meal, enzyme addition and diet form, respectively.

a-b: For each of the main factors, means bearing common superscripts are not significantly different ( $\mathrm{P} \leq 0.05)$.

NS: Not significant, *: Significant at $P<0.05$. 
Hens fed the 20\%-CCM diets also exhibited an insignificant increase in EYC as compared to the other experimental groups of hens. However, neither dietary enzyme supplementation nor diet form (mash vs. pellets) had a significant effect on blood parameters of Silver Montazah laying hens, measured in the present study, regardless of the effects of other dietary factors (Table 4). There were significant interactions $(P<0.05)$ between dietary CCM level and enzyme addition on serum level of $\mathrm{CH}$ and activity of ALT in blood serum (Table 4). The interactions between dietary CCM level and diet form were also significant $(\mathrm{P}<0.05)$ for serum level of $\mathrm{CH}$ and activities of ALT and AST in blood serum. Enzyme addition by diet form interactions were only significant $(P<0.05)$ for activity of $A L T$ in blood serum. The interactions among all dietary factors (i.e. $A B C$ interactions) were significant $(P<0.05)$ for $E Y C$ and serum level of $C H$ and activities of ALT and AST in blood serum (Table 4).

There is no clear explanation for the increased levels of serum and egg yolk cholesterol of hens fed the $30 \%$ CCM-containing diets as opposed to those of hens fed the control diet; this erratic observation may be resulted from a certain type of laboratory technical errors. On the other hand, means of all blood serum parameters, measured in the present study (including cholesterol) and egg yolk cholesterol, are comparable to those reported by Freeman (1984), Cerolini et al. (1990), Bragagnolo and Rodriguez-Amaya (2003) and Campbell (2004), regardless of the effect of dietary treatments.

\section{CONCLUSION}

Based on the obtained results, corn-with-cobs meal can be included up to $30 \%$ in diets of Silver Montazah laying hens, without compromising their productive performance or egg quality, with no need for pelleting the diets or adding exogenous enzymes.

\section{REFERENCES}

Adeyemi, O.A. and F.O. Familade (2003). Replacement of maize by rumen filtrate fermented corn-cob in layer diets. Bioresour.Technol., 90 (2): 221-224.

Al Bustany, Z. and K. Elwinger (1988). Whole grains, unprocessed rapeseed and $\beta$-glucanase in diets for laying hens. Swedish J. Agric. Res., 18: 31-40.

Allain, C.A.; L.S. Poon; C.S.G. Chang; W. Richmond and P.C. Fu (1974). Enzymatic determination of total serum cholesterol. Clinical Chemistry, 20:470-475.

Almirall, M.; R. Cos; E. Esteve-Garcia and J. Brufau (1997). Effect of inclusion of sugar beet pulp, pelleting and season on laying hen performance. British Poultry Sci., 38(5): 530-536.

AOAC; Association of Official Analytical Chemists (1990). Official Methods Of Analysis, $15^{\text {th }}$ edition, Washington, USA.

Attia, Y.A; S.A. Abd El-Rahman and A.K. Kies (2001). Utilization of vegetable diets containing different levels of rice bran with or without commercial enzymes in Norfa laying hens. J. Agric. Sci., Mansoura Univ., 26(6): 3547-3567. 
Bedford, M. (1996). The effect of enzyme on digestion. J. Appl. Poultry. Res. 5: 370-378.

Bedford, M. R. and A.J. Morgan (1996). The use of enzymes in poultry diets. World's Poultry Sci. J., 52:61-68.

Bedford, M. R. and G.G. Partridge (2003). Enzymes in Farm Animal Nutrition. Edited by Bedford, M. R. and G.G. Partridge, CAB International publishing, Finnfeeds Marlborough Wiltshire, UK.

Berto, A.D.; E.A. Garcia; C. Móri; A.B.G. Faitarone; K. Pelícia and A.B. Molino (2007). Performance of Japanese quails fed feeds containing different corn and limestone paticle sizes. Brazilian J. Poultry Sci., 9(3): 167-171.

Bragagnolo, N. and D.B. Rodriguez-Amaya (2003). Comparison of the cholesterol content of Brazilian chicken and quail eggs. Journal of Food Composition and Analysis, 16: 147-153.

Campbell, T.W. (2004). Blood biochemistry of lower vertebrates. In: $55^{\text {th }}$ Annual Meeting of the American College of Veterinary Pathologists (ACVP) AND 39th Annual Meeting of the American Society of Veterinary Clinical Pathology (ASVCP), edited and published by ACVP and ASVCP, Middleton WI, USA.

Cerolini, S.; A. Baldi and L.G. Cavalchini (1990). Blood and plasma biochemical variables in laying hens of different strains and ages. Arch. Geflügelk., 54: 190-194

Deaton, J.W.; B.D. Lott and J.D. Simmons (1989). Hammer mill versus roller mill grinding of corn of commercial egg layers. Poultry Sci., 68: 13421344.

Doumas, B.T.; W.A. Watson and H.G. Biggs (1971). Albumin standards and the measurement of serum albumin with bromocresol green. Clin. Chim. Acta, 31: 87-96.

Duncan, D.B. (1955). The multiple range and multiple F. tests. Biometrics, 11: $1-42$.

El-Deek, A.A.; M.A. Aser; Y.A. Attia and Amal A. Soliman (2003). Productivity of broiler breeder hens when fed practical or vegetable diets containing high levels of barley, sunflower meal or barley and sunflower meal without or with enzyme mixture supplementation: 1. Barley. Egyptian Poultry Sci., 23(2): 239-257.

FAO (2004). Animal Feed Resources Information System. Zea mays. № 549. FAO. Roma. pp: 1-4. www.fao.org/ag/aga/agap/frg/afris/data/549.htm.

Francesch, M.; A. Perez-Vedrell; E. Esteve-Garcia and J. Brufau (1995). Enzyme supplementation of a barley and sunflower-based diet on laying hen performance. J. Appl. Poultry Res., 4: 32-40.

Freeman, B.M. (1984). Appendix: Biochemical and Physiological data. In: Physiology and Biochemistry of the Domestic Fowl, Vol. 5, edited by Freeman, B.M., pp. 407-424, Academic Press, London, UK.

Goldenberg, H. and A. Fernandez (1966). Simplified method for estimation of inorganic phosphorus in body fluids. Clinical chemistry, 12: 871-882.

Haugh, R.R. (1937). The Haugh unit for measuring egg quality. United States Egg and Poultry Magazine, 43: 552-555, 572- 573. 
Henry, R.J. (1964). Clinical Chemistry: Principles and Technics, Harper and Row Publishers, New York.

Ingr, I.; J. Simeonová; J. Stávková; E. Petrovský and F. Dostál (1987). Cholesterol content in market hen eggs. Nahrung, 31: 933-940

Jackson, M.E.; D.W. Fodge and H.Y. Hsiao (1999). Effects of $\beta$-mannanase in corn-soybean meal diets on laying hen performance. Poultry Sci., 78: 1737-1741.

Jalal, M.A. and S.E. Scheideler (2001). Effect of supplementation of two different sources of phytase on egg production parameters in laying hens and nutrient digestibility. Poultry Sci., 80: 1463-1471.

Longe, O.G. and N.E.E. Ogedegbe (1989). Influence of fibre on metabolisable energy of diet and performance of growing pullets in the tropics. British Poultry-Sci., 30(1): 193-196.

Martínez, M.; V.J. Moya; E. Blas and C. Cervera (2008). The use of maize ear in rabbit diets: nutritive value and effect on fattening performance. Agrociencia, 42(2): 151-156.

McCracken, K.J.; R. Urquhart and M.R. Bedford (1993). Effect of heat treatment and enzyme supplementation of barley-based diets on performance of broiler chicks. Proceedings of Nutrition Society 52, 50A.

McCracken, K.J. (2002). Effects of physical processing on the nutritive value of poultry diets. Chapter 16 in: Poultry Feedstuffs: Supply, Composition and Nutritive Value, edited by McNab, J.M. and K.N. Boorman, CAB International, pp. 301-316.

NRC; National Research Council (1994). Nutrient Requirements of Poultry, 9th Edition, National Academy Press Washington DC., USA.

Rabie, M.H. (2004). Utilization of rice polishings in mash or pelleted diets for "mule ducklings". J. Agric. Sci. Mansoura Univ., 29(5): 2285 - 2301.

Reitman, S. and S. Frankel (1957). A colorimetric method for the determination of serum glutamic oxaloacetic and glutamic pyruvic transaminases. Amer. J. Clin. Pathol., 28: 56-63.

Roberts, J.R. and M. Choct, (2006). Effects of commercial enzyme preparations on egg and eggshell quality in laying hens. Br. Poultry Sci., 47: 501-510.

SAS Institute (1990) SAS® User's Guide. Statistics version $6^{\text {th }}$ ed., SAS Intstitute Inc., NC. USA.

Scott, M.L.; M.C. Nesheim and R.J. Young (1976). Nutrition of chicken, $2^{\text {nd }}$ edition, published by Scott, M. L. and Associates, Ithaca, New York.

Senkoylu, N.; H. Akyurek and H.E. Samli (2004). The possibilities of using high oil-sunflower meal and enzyme mixture in layer diets. Pakistan J. Nutr., 3(5): 285-289.

Tietz, N.W. (1987). Fundamentals of Clinical Chemistry, $3^{\text {rd }}$ edition, published by W.B. Saunders Co., Philadelphia, PA.

Van der Klis, J.D.; H.A.J. Versteegh; P.C.M. Simons and A.K. Kies (1997). The efficacy of phytase in corn-soybean meal-based diets for laying hens. Poultry Sci., 76: 1535-1542.

Wahlström, A.; R. Tauson and K. Elwinger (1999). Production and egg quality as influenced by mash or crumbled diets fed to laying hens in an aviary System. Poultry Sci., 78: 1675-1680. 
Wu G., M.M. Bryant, R.A. Voitle, and D.A. Roland (2005). Effects of $\beta$ mannanase in corn-soy diets on commercial leghorns in second-cycle hens. Poultry Sci., 84: 894-897.

Yakout, H.M.; M.M. Shehata; M.E. Omara and E.H. El-Ganzory (2003). Effect of energy level on the response of Mandarah hens to enzymesupplemented diets. Egyptian Poultry Sci., 23(IV): 859-873.

Zelenka, J. (2003). Effect of pelleting on digestibility and metabolisable energy values of poultry diet. Czech J. Anim. Sci., 48(6): 239-242.

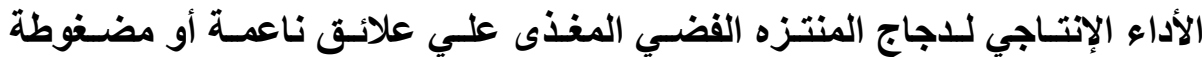

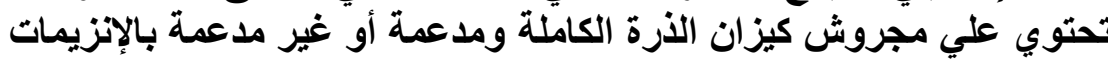

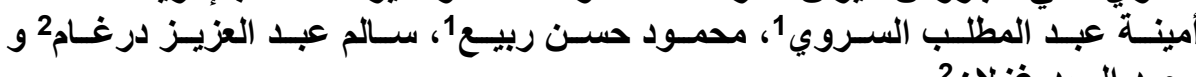

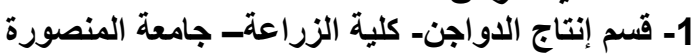

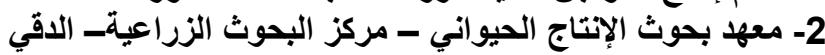

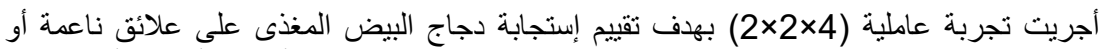

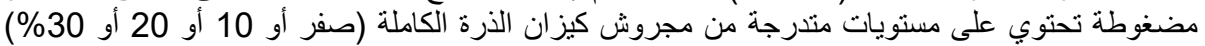

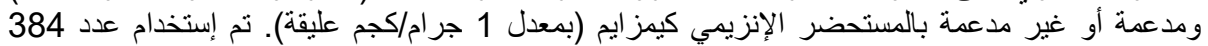

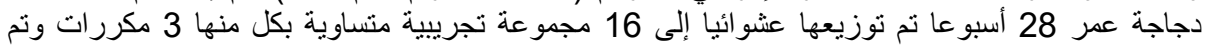

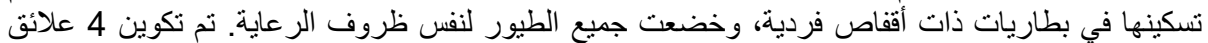

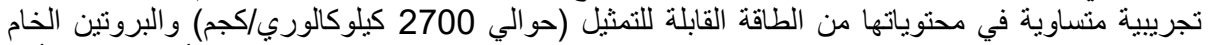

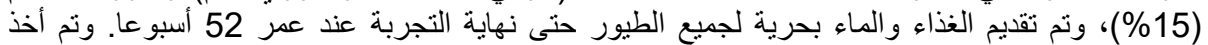

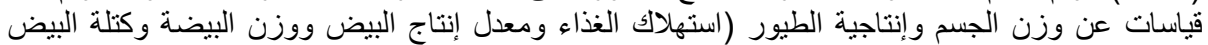

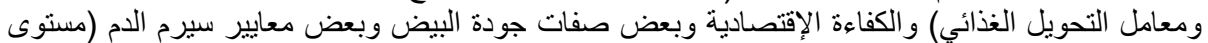

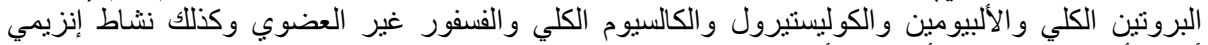

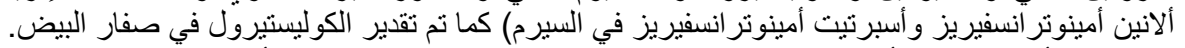

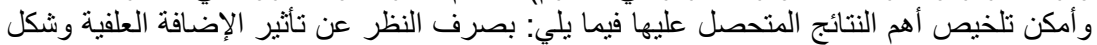

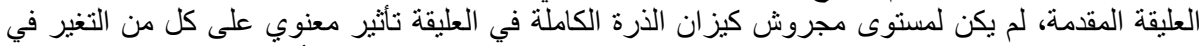

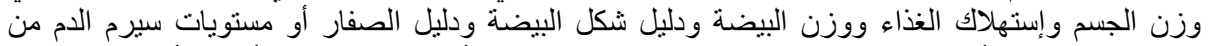

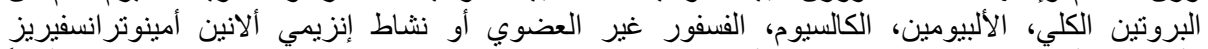

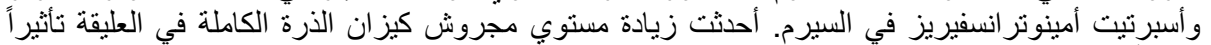

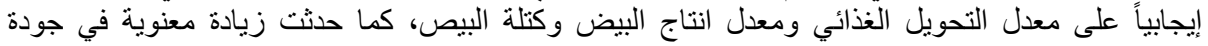

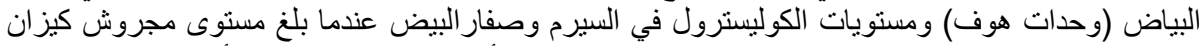

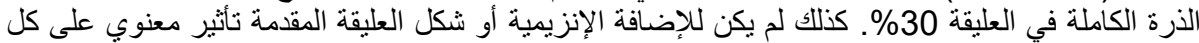

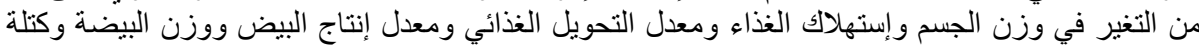

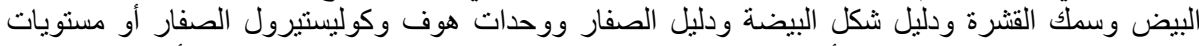

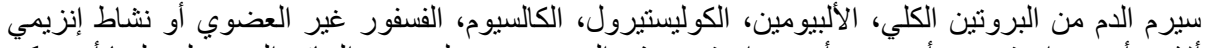

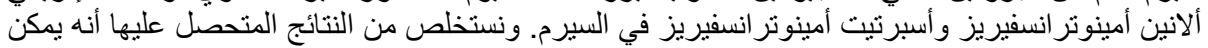

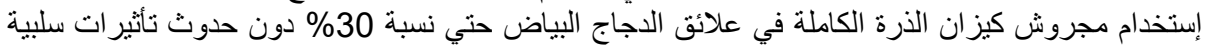
علي أدائها الإنتاجي أو جودة البيض مع عدم الحاجة إلى تصنيع العليقة في شكل محببات أو إضافة الإنزيمات التات 